Research Article

\title{
Determinants of Investment Timing of Government Venture Capital Guiding Funds in China
}

\author{
Jing Cui $\mathbb{D}^{D}$, Shuqin Zhang, Xianan Yin $\mathbb{D}$, and Kun Xu \\ School of Management, Beijing Union University, Beijing 100101, China \\ Correspondence should be addressed to Xianan Yin; gltxianan@buu.edu.cn
}

Received 22 June 2021; Accepted 29 July 2021; Published 4 August 2021

Academic Editor: Daqing Gong

Copyright ( $) 2021$ Jing Cui et al. This is an open access article distributed under the Creative Commons Attribution License, which permits unrestricted use, distribution, and reproduction in any medium, provided the original work is properly cited.

\begin{abstract}
With the prosperity of venture capital, all kinds of government venture capital guiding funds have sprung up, and the scale is explosive growth. However, the current investment of government guiding funds in enterprises has not fundamentally solved the financial difficulties in the early development of enterprises. This study examines the determinants of investment timing of government guiding funds. We investigate this question using the data of China's new three board companies that have been invested by government guiding funds in the year of 2015-2016. We find that government guiding funds enter the enterprises into developed areas earlier. The innovation ability and the market competitiveness of the invested enterprises are positively correlated with the investment timing of government guiding funds. There is no significant relationship between the investment proportion of government guiding funds and the timing of entering the enterprises. The research of this paper can provide theoretical reference for the subsequent optimization of the resource allocation and provide ideas and methods for the policy improvement and management optimization of government venture capital guiding funds in the future.
\end{abstract}

\section{Introduction}

In recent years, the global economic growth is slowing down, and the overall economic situation is leveling off, so economic growth is no longer the focus of Chinese government economic work; the government is turning to target on both the upgrading of industrial structure and economic transformation. It can be seen from the experience of developed countries, emerging industries, especially high-tech industries, play a crucial role in upgrading industrial structure and economic transformation, and early growth of venture enterprises is of great significance for the development of emerging industry. However, due to the high risk and huge uncertainty in the process of early operating stage, startup companies find it difficult to get financial support from the credit markets. Because of the rapid development of Chinese venture capitals in last several years, to a certain extent, early startups' financing difficulties are eased. But the ultimate goal of market-oriented venture capital institutions is gaining investment income. Although venture capital institutions pursue more profit, they also avoid more risk, so they are willing to invest enterprises which grow rapidly and have relatively mature business and management models, because there is more operating uncertainty and longer investment recovery cycles in the early stage $[1,2]$. Therefore, as a market-oriented investment behavior, venture investments cannot solve problems in early startup financing, which will lead to "market failure" in the field of venture capital. In this case, the government needs to deal with the problem of early startup financing, but what the government does should base on "no government failure." Under the premise of government intervention and "no government failure," setting up government guiding funds has become a new governmental way to solve the problem of early startup financing.

The governments support the development of domestic venture capital by guiding and attracting social capital in many developed countries, such as the United States, Israel, Australia, and Britain. By exploring different kinds of models of government involvement, these countries have established relatively complete and mature operational systems to create favorable environment for new industries 
and emerging industries. According to the experience of these countries, the governmental financial intervention has played an important strategic role in attracting social capital into the field of venture investment and fostering the growth of emerging industry. Traditionally, the main way of government support in China is giving grants to small- and medium-sized enterprises, including tax allocation, tax allowance, and exemption. These measures are superficially comprehensive, but less effective because they are lacking pertinence and unable to accurately include the developing trend in different industries and enterprises. Furthermore, the subsidies and tax reduction policies are inefficient in supporting the industrialization of innovation results, which not only causes the invalid use of public funds but also is easy to cause corruption because of the opaque decision-making on utilization of funds. Therefore, the government should do something to avoid "government failure." In recent years, government guiding funds gather the advantages of government and market and have become an important way for government to support the development of new industries and venture enterprises.

With the prosperity of domestic venture capital, various modes of government guiding funds have developed well, even mushroomed explosively. Government guiding funds are set up by the government and operate in market-oriented ways. But they do not invest directly in the enterprises and mainly guide more social capital into the field of venture capital by various ways. As investment entities, subfunds which are invested by both the government and social funds are set up and offer money to set-ups. Different from the general commercial venture capital, the main purpose of government guiding funds is not to invest in startup companies and exit in the future for financial revenues. As a policy tool of supporting the development of early venture enterprises, government guiding funds support entrepreneurial enterprises, especially for the high-technology enterprises. Thus, government guiding funds have more obvious attributes of public policy. In addition, government guiding funds can make full use of the leverage effect of financial capital and attract more social capital to participate in venture investment, so the intervention from market force is greatly significant to government guiding funds. On the one hand, by leveraging, government guiding funds can attract more social funds to support more startups. On the other hand, the participation of social capital also makes up for the governmental shortage of the ability and experience in investment management, so as to promote rational and effective allocation of resources.

In essence, government guiding funds have Chinese characteristics which are based on the experience of public venture capital fund. However, because government guiding funds have operated in a short time, the market-oriented operating strategy and management mode have not been effective. Furthermore, there are still many problems in policy making and implementation; one of the most important problems is the investment timing of government guiding funds. Through the analysis of data, we found that only $5 \%$ enterprises that were invested by government guiding funds are in their early stage and most of them are in the expansion and maturity period, as shown in Figure 1. It can be seen that the investments by government guiding funds cannot fundamentally solve the financial difficulties of the enterprises in the early stage. Which factors affect the investment choice by government guiding funds? It is the core research issue in this paper. We hope that this paper can offer a theoretical reference to optimize the allocation of resources and provide ideas and methods for policymakers to improve and maximize the efficiency of government guiding funds in the future.

This paper discusses the determinants of the investment timing of government guiding fund in China. First of all, this paper systematically combs the theoretical foundation and research results of government guiding funds. Secondly, we collect the data of investments by government guiding funds. Then, we use Ologit model to test the influencing factors of investment timing of government guiding funds empirically. Finally, according to the empirical results, policy recommendations are put forward. By the research in this paper, we find that (1) government guiding funds enter the enterprises into developed areas earlier; on the contrary, the enterprises in the underdeveloped areas obtain the funds later. (2) The innovation ability of the invested enterprises is positively correlated with the investment timing of government guiding funds; that is to say, government guiding funds are more willing to invest in enterprises with low innovation capacity in the initial stage. (3) The market competitiveness of the invested enterprises is positively related to the opportunity of government guiding funds' entering into the enterprises. Namely, the better the enterprises' market competitiveness is, the later the government guiding funds invest them. (4) There is no significant relationship between the investment proportion of government guiding funds and the timing of entering the enterprises.

\section{Literature Review}

2.1. The Incentive of Government Guiding Funds. Holmstrom and Milgrom pioneered a study of the importance of public venture capital funds, especially for the projects that are not attractive to private venture capital [3]. Scholars have found that public venture capital funds promote the development of venture capital and private equity investment $[4,5]$, which can help to solve market failure (Maula and Murray). Some studies also showed that public venture capital funds have no impact on social venture capital [6], and even public venture capital funds have an extrude effect on social venture capital [7].

The subsequent researches include the effectiveness of public venture capital funds for entrepreneurial growth, supporting the investment of young high-tech enterprises in Europe [8], enterprise innovation [9], entrepreneurial success [10], sales volume and employee number of venture enterprises [11], enterprise performance [12], and enterprise financing [13]. Some studies have compared the incentive differences between public venture capital funds and private venture capital funds [14]. These studies are also significant progress in the study of the impact of fiscal policy on enterprise economic performance [15]. 


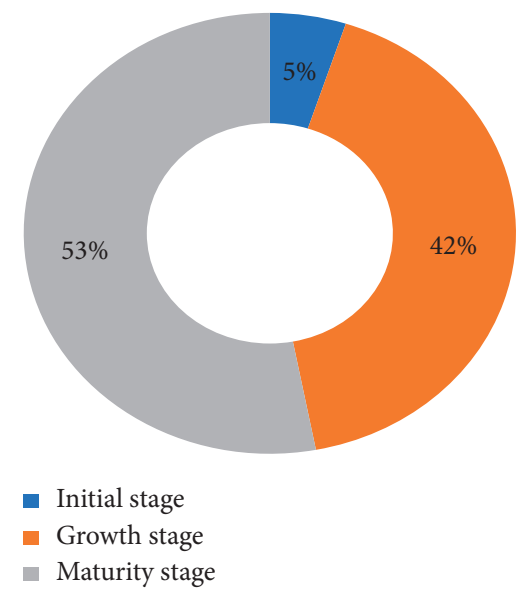

FIgURE 1: 2015-2016 statistics of investment timing.

Researches in China on government guiding funds are still in their infancy. Some studies found that government guiding funds have a guiding effect for venture capital and private equity investment but are dramatically different in different regions [16]. There are also researches on the limitations of the guiding role [17], and some researches even found that there is no impact on the social venture capital [18]. On how to improve the guiding effect, scholars believe that we can draw lessons from the financing guarantee methods of the American SBIC program [19], design the compensation for the loss of private capital, improve supply quantity, optimize the benefit compensation mechanism [20], and improve the level of marketization [21]. Huang (2016) paid close attention to the impact of government venture funds on enterprise innovation [22].

\subsection{Government Guiding Funds' Operational Mode and} Supervision. Government guiding funds are actually funds of funds, and the specific investments are undertaken by subfunds, which mainly invest in startups. The government is not directly involved in the investment of the guiding funds, does not participate in the operation of subfunds, is responsible for the formulation and implementation of all kinds of support policies, and provides a good external investment environment. Chen considers that the operating mode of foreign public venture funds can be divided into three categories: equity participation mode, financing guarantee mode, and diversified supporting mode. In China, Shanghai model, Shenzhen mode, and Tianjin mode are typical representatives [23]. Yang supposes that resource replenishing effect is the key to promoting the fundraising of venture capital institutions by the participation of government guiding funds [24].

The supervision of government guiding funds emphasizes supervising, restraining, and motivating the leaders of the management institutions [19] and setting up management systems with hierarchical and different dimensions [24], so as to make both public capital and private capital reach the optimal contract choice. Scholars have constructed different performance evaluation systems of government guiding funds, including internal rate of return, economic benefit, policy effect economic efficiency, and management effect $[25,26]$.

2.3. The Investing Timing of Government Guiding Funds. There are less research studies on the investment timing of government guiding funds. Government guiding funds are not commercial venture capital funds, so their pursuit is not for more profit; the investment by government guiding funds should conform to the national industrial policy and high-technology industrialization. Moreover, government guiding funds should enter into startups in seed or early stage, so as to make up the shortfall of the investment by social capital in small- and medium-sized enterprises in the early stage and overcome market failure [27]. When enterprises enter the developing period, the financing difficulties are effectively solved, and then, government guiding funds can gradually withdraw from them.

2.4. Literature Summary. Through the previous literatures, it can be found that most of the literatures take "government guidance + marketing operation" as the operating core of government guiding funds. The government does not invest directly in venture enterprises but guides the social capital to set up new venture capital funds jointly by financial contribution. On the one hand, it can attract more social capital by the endorsement of government credit. On the other hand, the participation of market institutions makes up for the shortage of the government institutions in the investment professionalism and indirectly improves the efficiency of financial funds, thus achieving the purpose of supporting the development of startups and promoting the upgrading of industrial structure. However, there are few literatures on the investment timing of government guiding funds; it is a problem worth researching at present. The right timing can make the government guiding funds play a greater role, but the incorrect timing often leads to low returns and the small effect on the enterprises and even investment failure. Therefore, this paper chooses to study the timing of government guiding funds' entering into the enterprises.

\section{Theoretical Analysis and Hypothesis Presentation}

3.1. The Development of Areas Where the Invested Enterprises Are Located and Investment Timing. Developed financial markets tend to appear in economically developed areas, and the role of financial markets is to provide fair and open trading places for both parties. Murray found that the supply of venture capital has a great relationship with the maturity of the financial market, and there is a positive correlation between them. The more developed the financial market is, the more beneficial it is to raise funds. Subsequently, the return rate of venture capitalists will increase and the supply of venture capital increases. The better development in the region, the more likely the enterprises to contact with the advanced international experience in science, technology, and management, which can inspire the entrepreneurial enthusiasm of entrepreneurs and create high-quality 
startups. The venture enterprises with market potential are the investment objects of risk institutions, which drive the demand for venture capital. The more developed the region economy is, the more conducive it is to the development of venture capital. Good capital liquidity can shorten the time during which venture capital firms raise funds from ordinary investors and increase the speed and scale of venture capital investments.

In general, the higher the urban development degree is, the richer the managerial experience of venture capital' operating organization is. So good enterprises can be caught in the early stage, and venture capital can enter into them earlier. That is to say, enterprises in developed area have lower financing constraints than them in underdeveloped area. Therefore, for the enterprises in the first-tier cities, government guiding funds may enter into the enterprises in the later stage, but for the enterprises in the less developed areas, government guiding funds may enter into the enterprises in the initial stage.

Hypothesis 1. The development of the areas where the invested enterprises are located is positively correlated with the timing of the government guiding funds' entering into them.

\subsection{The Invested Enterprises' Innovation Ability and Invest-} ment Timing. Because of different resource constraints faced by small and medium-sized enterprises (SMES) and large enterprises in initial period, SMES often obtain relatively high income depending on low input to seek survival and development with high uncertainty. For SMES in initial period, risk is their advantage and innovation is the lifeline. So in theory, high risk activities such as the innovations of technology, product, and business model often depend on SMES rather than mature ones in a country's economic system.

In the initial stage, the enterprises have few patents and low ability of innovation. The technology input and technology market faced by enterprises are uncertain. With the continuous development, the number of patents and the innovation ability are increasing, the technologies and products are relatively mature, and then the enterprises have clear ideas to develop and become much stronger. It has greatly promoted the increase in the number of patents, but the innovation performance has not reached a certain scale. In the later stage of operation, the number of patents will increase slowly, and enterprises pay more attention to enhance their profitability. Government guiding funds are different from the commercial funds, which invest in enterprises with high level of operating performance and smaller operational risk to gain more profit. But government guiding funds mainly serve industrial upgrading and support the development of high-tech enterprises. Therefore, government guiding funds choose to invest in enterprises which have low innovation ability, so as to help them to grow and establish enterprises' competitiveness.

Hypothesis 2. The innovation ability of the invested enterprises is positively correlated with the timing of the government guiding funds' entering into them.
3.3. The Invested Enterprises' Market Competitiveness and Investment Timing. Market competitiveness is meant to achieve market objectives, including improving market advantage, market share, market position, profitability, and so on. By the allocation of various resources owned by enterprises, enterprises can gradually surpass the competitors' performance. Market competitiveness is the fundamental and core advantage of enterprises, which also has an impact on the financing choice. Because of the limited resources owned by SMES, the prospect in the future is difficult to reasonably estimate; then there is great information asymmetry between the external investors and the entrepreneurs, which affects the feasibility of financing. The external investors will pay much attention to market competitiveness of SMES because market competitiveness is an important reference for investment.

With the development of the enterprises, the investment risk will decrease and the income will increase constantly; therefore, market competitiveness of the enterprises will gradually increase. It is difficult for the enterprises to obtain market competitiveness at the early stage, but it will continuously strengthen the process of enterprises' development. Therefore, government guiding funds will choose to enter into the enterprises when they have been operating for a period of time and have certain market competitiveness.

Hypothesis 3. Market competitiveness of the invested enterprises is positively correlated with the timing of the government guiding funds' entering into them.

\subsection{The Investment Proportion of Government Guiding Funds} and Investment Timing. In the early period of business operation, the investment proportion of venture capital is relatively large because the enterprise founders have less capital and creditors are reluctant to lend them money. With the development step by step, profit and reinvestment of enterprises are increasing; that is to say, the enterprises have been on the right operational track. At the same time, the owners of the enterprises do not want to decentralize the share ownership structure, so they may use more bond financing when raising funds. Therefore, the proportion of equity investment from venture capital is smaller in the early stage.

Government guiding funds are referred to as funds of funds (FOF) and have their own particularity. Government guiding funds hope to invest in seed and early staged companies, so as to make up for the shortage of the general venture capital which invests primarily in enterprises in the growing and mature period. However, according to the theory of venture capital, the enterprises' risk is larger in the early operating stage. With the development of the enterprises, the main risks will reduce. The original intention of setting up government guiding funds is to solve the problem of capital needs of the startups in the early stage, but government guiding funds adopt the market-oriented operating mode, and fund managers have pressure to maintain and increase the value of state capital. In order to avoid the risk, the fund managers are more willing to invest more in the 
enterprises which have been operating for a period, so the investment of government guiding funds in the initial stage is less.

Hypothesis 4. The proportion of investment by government guiding funds is positively correlated with investment timing.

\section{Data, Sample Description, and Equations}

4.1. Data. In this paper, the data of the investment by government guiding funds and the invested enterprises are from Zero2IPO Research Center. The data of enterprises' innovation comes from the patent database of the National Intellectual Property Office. And the enterprises' information and financial information are from Wind Database. The data analysis software is STATA14.

4.2. Sample Description. Our sample firms are China's new three board companies that have been invested by government guiding funds in the year of 2015-2016, and the selected data are reasonably screened. After screening, 207 effective data have been obtained. The screening criteria are as follows:

(1) Exclude the data of the industries that are not clear or the industries that cannot be judged

(2) Eliminate the data in which the investment stage is not clearly identified

(3) Delete the data in which other variables are incomplete

4.3. Variable Definitions. According to the aim of this study, the explanatory variables, explanatory variables, and other variables that are defined are shown in Table 1.

4.4. Empirical Models. To test the hypothesis, we use the following Ologit model:

$$
\begin{aligned}
\text { TIME }= & \alpha_{0}+\alpha_{1} \text { AREA }+\alpha_{2} \text { PATENT }+\alpha_{3} \text { POWER } \\
& +\alpha_{4} \text { EQUITY }+\alpha_{5} \text { AREA } * \text { EQUITY } \\
& +\alpha_{6} \text { AGE }+\alpha_{7} \text { CAPITAL }+\alpha_{8} \text { ASSET } \\
& +\alpha_{9} \text { LIA }+\alpha_{10} \text { REV }+\varepsilon .
\end{aligned}
$$

\section{Analyses and Results}

5.1. Descriptive Statistics. Summary statistics of the data are provided in Table 2. It can be seen that the average investment timing (TIME) is 2.435 , indicating that the investment by government guiding funds is mainly in the growth and maturity stage. The mean value of the area (AREA) where the invested enterprise is located is 0.396 , indicating that most of the invested enterprises are in the second-tier cities and below, and the proportion of investment enterprises in Beijing, Shanghai, Guangzhou, and Shenzhen is $39.6 \%$. The average number of patents
(PATENT) is 33.27. The average value of the investment share ratio (EQUITY) is $5.249 \%$, indicating that the share ratio of the investment by government guiding funds is over $5 \%$. The mean value of the operating years (AGE) is 11.53 , indicating that the average age of China's new three board companies in our sample is more than 11 years. The average value of natural logarithm of the registered capital is 8.6929. The average size of assets is 9.7222 . The average growth rate of operating income is $27.2 \%$, and the average value of the industry type (INDU) of the invested enterprise is 0.609 , indicating that $60.9 \%$ of the sample companies belongs to the tertiary or quaternary industries.

5.2. Correlation Analysis. The correlation matrix is in Table 3. The correlation coefficients between variables are all less than 0.5 , indicating that there is a weak correlation between variables and no multicollinearity exists.

\subsection{Empirical Analysis}

5.3.1. Empirical Analysis of Full Sample. Table 4 is the multiple regression result of the Ologit model that tests the timing of government guiding fund's entering into enterprises. The first column contains only the regression results of the control variables, the second column is the regression result that only contains the explanatory variables, and the third column is the regression result containing both the explanatory variable and the control variable.

From the statistical results of model (3), we can see the following.

The regression coefficient of the development of the area in which the invested enterprise is located (AREA) is -1.7073 ; that is significant in $5 \%$ level, so Hypothesis 1 is not established. Namely, in the economic developed area, government guiding funds enter into the enterprises earlier. This result is contrary to the theoretical assumption. Because the quantity and scale of government guiding funds are growing rapidly, the regional distribution is unbalanced. Chinese government guiding funds are mainly in developed eastern region. Another issue around government guiding funds in China is the risk of assimilation with social capital. The subfunds of government guiding funds may choose to invest enterprises with low financing constraints, so they have smaller investment risk and gain more profit.

If we hope government guiding funds realize the guidance effect, the investment preference and behaviors of the subfunds of government guiding funds should be significantly different from pure commercial funds, so that the synergistic effect and " $1+1>2$ " will be formed. However, there is no significant difference in final investment preferences in China between subfunds of government guiding funds and social funds. In this case, the development of government guiding funds may deviate from the original intention; the bootstrap effect is difficult to implement. The larger the government guiding funds, the greater the adverse impact. The risk of assimilation is a big systemic risk in the development process of government guiding funds. 
TABLE 1: The definition of the variables.

\begin{tabular}{|c|c|c|c|}
\hline Variable types & Factor types & $\begin{array}{l}\text { English } \\
\text { symbols }\end{array}$ & Interpretative statement \\
\hline $\begin{array}{l}\text { Explanatory } \\
\text { variables }\end{array}$ & Investment timing & TIME & $\begin{array}{l}\text { The initial period }=1 \text {, expansion period }=2 \text {, and maturity } \\
\text { period }=3\end{array}$ \\
\hline \multirow{4}{*}{$\begin{array}{l}\text { Explanatory } \\
\text { variables }\end{array}$} & $\begin{array}{l}\text { The development of the areas where the } \\
\text { invested enterprises are located }\end{array}$ & AREA & $\begin{array}{l}\text { A dummy variable equal to one for first-tier city } \\
\text { (and zero otherwise) }\end{array}$ \\
\hline & $\begin{array}{c}\text { The innovation ability of the invested } \\
\text { enterprises }\end{array}$ & PATENT & The number of patents \\
\hline & $\begin{array}{l}\text { The market competitiveness of the } \\
\text { invested enterprises }\end{array}$ & POWER & Operating profit/operating income \\
\hline & $\begin{array}{l}\text { The proportion of investment by } \\
\text { government guiding funds }\end{array}$ & EQUITY & $\begin{array}{l}\text { Share ratio of subfunds of government guiding funds in } \\
\text { enterprises }\end{array}$ \\
\hline \multirow{5}{*}{$\begin{array}{l}\text { Control } \\
\text { variables }\end{array}$} & The age of the invested enterprises & AGE & The operating years of the invested enterprises \\
\hline & $\begin{array}{c}\text { The registered capital of the invested } \\
\text { enterprises }\end{array}$ & CAPITAL & Natural logarithm of the number of registered capital \\
\hline & $\begin{array}{c}\text { The size of total assets in the invested } \\
\text { enterprises }\end{array}$ & ASSET & Natural logarithm of total assets \\
\hline & $\begin{array}{c}\text { The capital structure of the invested } \\
\text { enterprises }\end{array}$ & LIA & Liabilities/total assets \\
\hline & The growth of the invested enterprises & REV & Growth rate of the operating income \\
\hline $\begin{array}{l}\text { Grouping } \\
\text { variables }\end{array}$ & $\begin{array}{l}\text { The type of industries which the invested } \\
\text { enterprises belong to }\end{array}$ & INDU & $\begin{array}{l}\text { A dummy variable equal to one for the tertiary and quaternary } \\
\text { industries, and zero for the primary and secondary industries }\end{array}$ \\
\hline
\end{tabular}

TABLE 2: Summary statistics.

\begin{tabular}{lccccc}
\hline Variable & Mean & Sd & Min & Max & p50 \\
\hline TIME & 2.435 & 0.525 & 1 & 3 & 2 \\
AREA & 0.396 & 0.490 & 0 & 1 & 0 \\
PATENT & 33.27 & 91.11 & 0 & 1000 & 7 \\
POWER & 0.0283 & 0.280 & -0.952 & 0.450 & 0.101 \\
EQUITY & 5.249 & 4.662 & 0.210 & 18.46 & 4 \\
AGE & 11.53 & 4.622 & 5 & 22 & 11 \\
CAPITAL & 8.6929 & 0.9836 & 6.5028 & 11.0165 & 8.6247 \\
ASSET & 9.7222 & 1.2866 & 6.7595 & 13.4269 & 9.6627 \\
LIA & 0.320 & 0.184 & 0.0364 & 0.741 & 0.280 \\
REV & 0.272 & 0.308 & -0.583 & 0.846 & 0.282 \\
INDU & 0.609 & 0.489 & 0 & 1 & 1 \\
\hline
\end{tabular}

The regression coefficient of the innovation ability of the invested enterprise is 0.0055 , which is significantly positive at the $1 \%$ level. Therefore, Hypothesis 2 is established. In the initial period, the enterprises have weak innovation ability. With the continuous development of the enterprises, the innovation ability enhances, and the enterprises gradually obtain the innovation performance. Government guiding funds often choose to enter into enterprises in the initial period, so that they can support enterprises to establish competitive advantages in a short time.

The regression coefficient of the market competitiveness of the invested enterprises (POWER) is 1.3976, which is significantly positive at the $10 \%$ level. Therefore, Hypothesis 3 is established. That is, the stronger the market competition ability of the enterprises is, the later the government guiding funds enter into them, which can reduce the investment risk and gain the investment income quickly.

The regression coefficient of the proportion of government guiding funds' investment (EQUITY) is 0.0413 , but it is not significant. Therefore, Hypothesis 4 is not established; that is, the positive correlation between the investment timing of government guiding funds and the share proportion of the investment is not tested. However, the coefficient of the cross term between the development of the areas in which enterprises are located and the share proportion of government guiding funds' investment is -0.1988 , which is significantly negative at the level of $5 \%$. It shows that the share proportion of government guiding funds' investment in the developed areas is negatively related to the investment timing. That is, government guiding funds are more inclined to invest more in enterprises later in the first-tier cities; on the contrary, government guiding funds are willing to invest more in enterprises earlier in second-tier cities and below.

The regression results of control variables: the regression coefficient of the age of the invested enterprises (AGE) and the timing of government guiding funds' entry into enterprises (TIME) is 0.8027 , which is significant at $1 \%$ level. The later the guiding fund entering into the enterprises, the older the enterprises they will choose to invest.

The regression coefficient of the registered capital of the invested enterprises (CAPITAL) and the timing of government guiding funds' entry into enterprises (TIME) is 0 , which is not significant. The investment timing of government guiding funds' entering is not significantly related to the registered capital of invested enterprises.

The regression coefficient of the scale of invested enterprises (ASSET) is 0, but it is not significant. There is no significant relationship between the investment timing of government guiding funds and the scale of the invested enterprises.

The regression coefficient between the capital structure (LIA) of the invested enterprises and the timing when the government guiding funds enter into the enterprises (TIME) is -0.7432 , but it is not significant. It shows that there is no 
TABLE 3: Correlation matrix.

\begin{tabular}{|c|c|c|c|c|c|c|c|c|c|c|}
\hline & TIME & AREA & PATENT & POWER & EQUITY & AGE & CAPITAL & ASSET & LIA & REV \\
\hline TIME & 1 & & & & & & & & & \\
\hline AREA & -0.050 & 1 & & & & & & & & \\
\hline PATENT & $0.148^{* *}$ & 0.036 & 1 & & & & & & & \\
\hline POWER & $0.220^{* * *}$ & $0.185^{* * *}$ & 0.017 & 1 & & & & & & \\
\hline EQUITY & $-0.147^{* *}$ & -0.065 & -0.086 & -0.099 & 1 & & & & & \\
\hline AGE & $0.469^{* * *}$ & $0.157^{* *}$ & 0.056 & $0.173^{* *}$ & -0.111 & 1 & & & & \\
\hline CAPITAL & 0.130* & 0.093 & -0.058 & $0.237^{* * *}$ & $0.348^{* * *}$ & 0.093 & 1 & & & \\
\hline ASSET & $0.195^{* * *}$ & $0.131^{*}$ & -0.012 & 0.063 & $0.294^{* * *}$ & $0.175^{* *}$ & $0.479^{* * *}$ & 1 & & \\
\hline LIA & 0.035 & -0.078 & 0.014 & -0.041 & 0.044 & 0.0530 & 0.055 & $0.188^{* * *}$ & 1 & \\
\hline REV & $0.121^{*}$ & -0.019 & -0.013 & -0.035 & 0.011 & $\mathbf{0 . 1 9 8}^{* * *}$ & 0.035 & 0.096 & 0.006 & 1 \\
\hline
\end{tabular}

Note: variable definitions are in Table $3 .{ }^{*},{ }^{* *}$, and ${ }^{* * *}$ indicate significance at $10 \%, 5 \%$, and $1 \%$, respectively.

TABLE 4: Multiple regression results of full sample.

\begin{tabular}{|c|c|c|c|}
\hline & M1 & M2 & M3 \\
\hline AREA & & $\begin{array}{c}-0.6819 \\
(1.52)\end{array}$ & $\begin{array}{c}-1.7073^{* *} \\
(2.50)\end{array}$ \\
\hline PATENT & & $\begin{array}{c}0.0048 \\
(1.23) \\
\end{array}$ & $\begin{array}{c}0.0055^{* * *} \\
(3.48) \\
\end{array}$ \\
\hline POWER & & $\begin{array}{c}1.7396^{* * *} \\
(3.58)\end{array}$ & $\begin{array}{c}1.3976^{*} \\
(1.92)\end{array}$ \\
\hline EQUITY & & $\begin{array}{c}0.0006 \\
(0.02) \\
\end{array}$ & $\begin{array}{c}0.0413 \\
(0.57) \\
\end{array}$ \\
\hline AREA $^{*}$ EQUITY & & $\begin{array}{c}-0.1635^{* *} \\
(-2.44) \\
\end{array}$ & $\begin{array}{c}-0.1988^{* *} \\
(-1.96) \\
\end{array}$ \\
\hline AGE & $\begin{array}{c}0.7592^{* * *} \\
(5.61) \\
\end{array}$ & & $\begin{array}{c}0.8027^{* * *} \\
(5.26) \\
\end{array}$ \\
\hline CAPITAL & $\begin{array}{c}0.0000 \\
(1.23) \\
\end{array}$ & & $\begin{array}{c}0.0000 \\
(0.88) \\
\end{array}$ \\
\hline ASSET & $\begin{array}{c}0.0000 \\
(0.47) \\
\end{array}$ & & $\begin{array}{c}0.0000 \\
(0.04)\end{array}$ \\
\hline LIA & $\begin{array}{c}-1.1843 \\
(-1.16)\end{array}$ & & $\begin{array}{c}-0.7432 \\
(-0.73)\end{array}$ \\
\hline REV & $\begin{array}{c}1.1119^{* *} \\
2.11\end{array}$ & & $\begin{array}{c}1.1568^{* *} \\
(2.08)\end{array}$ \\
\hline$N$ & 207 & 207 & 207 \\
\hline Pseudo $R 2$ & 0.5676 & 0.0769 & 0.6036 \\
\hline$p$ & 0.0000 & 0.0000 & 0.0000 \\
\hline
\end{tabular}

Note: variable definitions are in Table $4 .{ }^{*},{ }^{* *}$, and ${ }^{* * *}$ indicate significance at $10 \%, 5 \%$, and $1 \%$, respectively.

significant correlation between the investment timing of government guiding funds and the capital structure of enterprises.

The regression coefficient of the growth of the invested enterprises (REV) and the timing when the government guiding funds enter into the enterprises (TIME) is 1.1568, and it is significant in the $5 \%$ level. It shows that the better the growth enterprises are, the later the government guiding fund enters, so as to obtain a stable high return at a short time.

5.3.2. Empirical Analysis of Subsamples in Primary and Secondary Industries. In China, four main industries are included: (1) the primary industry, including agriculture, forestry, animal husbandry, and fisheries; (2) the secondary industry, including mining, manufacturing, power, gas and water production and supply, and construction; (3) the tertiary industry, that is, the service industry; (4) the fourth industry, that is, the information industry. Because agriculture and industry are in the basic position of the national economy, and the nature of the service industry and to a certain extent the information industry is more similar, the sample firms are divided into two groups in this paper, one category includes the enterprises from the first two industries, the other category contains the enterprises from the tertiary and quaternary industry. The regression results of the subsample of the first two industries are shown in Table 5.

Through the analysis, it is found that the investment timing of government guiding funds has a negative correlation with the innovation ability of the invested enterprises, which is significant at the level of $10 \%$. This is opposite to the result of the full sample. This is mainly because the 
TABLE 5: Multiple regression results of subsample (1).

\begin{tabular}{|c|c|c|c|}
\hline & $M 1$ & M2 & M3 \\
\hline AREA & & $\begin{array}{c}-0.7697 \\
(0.85)\end{array}$ & $\begin{array}{c}-3.0884^{*} \\
(1.73)\end{array}$ \\
\hline PATENT & & $\begin{array}{c}0.0007 \\
(0.20) \\
\end{array}$ & $\begin{array}{c}-0.0052^{*} \\
(-1.95) \\
\end{array}$ \\
\hline POWER & & $\begin{array}{r}0.1227 \\
(0.08) \\
\end{array}$ & $\begin{array}{c}-5.0786 \\
(-1.35) \\
\end{array}$ \\
\hline EQUITY & & $\begin{array}{c}-0.0265 \\
(-0.48) \\
\end{array}$ & $\begin{array}{c}-0.0854 \\
(-0.52)\end{array}$ \\
\hline AREA *EQUITY & & $\begin{array}{c}-0.1040 \\
(-0.80) \\
\end{array}$ & $\begin{array}{c}-0.3813^{* *} \\
(-1.98)\end{array}$ \\
\hline AGE & $\begin{array}{c}0.9370^{* * *} \\
(2.92)\end{array}$ & & $\begin{array}{c}1.2103^{* *} \\
(2.41)\end{array}$ \\
\hline CAPITAL & $\begin{array}{c}-0.0000 \\
(-0.01)\end{array}$ & & $\begin{array}{c}-0.0000 \\
(-0.55)\end{array}$ \\
\hline ASSET & $\begin{array}{c}0.0000 \\
(0.64)\end{array}$ & & $\begin{array}{c}0.0000 \\
(0.12)\end{array}$ \\
\hline LIA & $\begin{array}{c}-0.3341 \\
(-0.15) \\
\end{array}$ & & $\begin{array}{c}2.5877 \\
(0.57) \\
\end{array}$ \\
\hline REV & $\begin{array}{c}2.1221^{* *} \\
(2.08)\end{array}$ & & $\begin{array}{c}4.0636^{* *} \\
(2.30) \\
\end{array}$ \\
\hline$N$ & 81 & 81 & 81 \\
\hline Pseudo $R 2$ & 0.5938 & 0.641 & 0.6731 \\
\hline$p$ & 0.6175 & 0.5172 & 0.6687 \\
\hline
\end{tabular}

Note: variable definitions are in Table $5 .{ }^{*},{ }^{* *}$, and ${ }^{* * *}$ indicate significance at $10 \%, 5 \%$, and $1 \%$, respectively.

TABle 6: Multiple regression results of subsample (2).

\begin{tabular}{|c|c|c|c|}
\hline & $M 1$ & $M 2$ & M3 \\
\hline AREA & & $\begin{array}{c}-0.8889 \\
(1.50)\end{array}$ & $\begin{array}{c}-2.4581^{* * *} \\
(2.68)\end{array}$ \\
\hline PATENT & & $\begin{array}{c}0.0093 \\
(1.21)\end{array}$ & $\begin{array}{c}0.0095^{* * *} \\
(3.09)\end{array}$ \\
\hline POWER & & $\begin{array}{c}2.0059^{* * *} \\
(3.61)\end{array}$ & $\begin{array}{c}1.9311^{* *} \\
(2.34)\end{array}$ \\
\hline EQUITY & & $\begin{array}{c}-0.0076 \\
(-0.12)\end{array}$ & $\begin{array}{c}0.1196 \\
(1.10)\end{array}$ \\
\hline AREA * EQUITY & & $\begin{array}{c}-0.1883^{* *} \\
(-2.02)\end{array}$ & $\begin{array}{c}-0.3311^{* *} \\
(-2.00)\end{array}$ \\
\hline AGE & $\begin{array}{c}0.6929^{* * *} \\
(4.44) \\
\end{array}$ & & $\begin{array}{c}0.8022^{* * *} \\
(4.20)\end{array}$ \\
\hline CAPITAL & $\begin{array}{c}0.0000 \\
(1.10)\end{array}$ & & $\begin{array}{c}0.0000 \\
(0.84)\end{array}$ \\
\hline ASSET & $\begin{array}{c}0.0000 \\
(0.74)\end{array}$ & & $\begin{array}{c}-0.0000 \\
(-0.01)\end{array}$ \\
\hline LIA & $\begin{array}{c}-2.4748^{*} \\
(-1.95) \\
\end{array}$ & & $\begin{array}{c}-2.0229 \\
(-1.34) \\
\end{array}$ \\
\hline REV & $\begin{array}{c}0.6655 \\
(0.95)\end{array}$ & & $\begin{array}{l}0.7680 \\
(0.92)\end{array}$ \\
\hline$N$ & 126 & 126 & 126 \\
\hline Pseudo $R 2$ & 0.5309 & 0.1181 & 0.6140 \\
\hline$p$ & 0.0000 & 0.0003 & 0.0000 \\
\hline
\end{tabular}

Note: variable definitions are in Table $6 .{ }^{*},{ }^{* *}$, and ${ }^{* * *}$ indicate significance at $10 \%, 5 \%$, and $1 \%$, respectively. management risk in the enterprises from the first two industries is relatively low comparing with the enterprises in the tertiary and quaternary industry. Although the innovation ability is relatively low, the possibility of turning capability into innovation performance is large, so the government guiding funds will invest in the enterprises from the first two industries in the early stage. The coefficient of market competitiveness (POWER) is not significant, and the other variables' significance is the same as that of the full sample.

5.3.3. Empirical Analysis of Subsamples in the Tertiary and Quaternary Industries. The regression result of the subsample of enterprises from the tertiary and quaternary industry is as follows. We find that the regression coefficient is consistent with the full sample (Table 6).

\section{Discussion and Conclusion}

From the perspective of enterprise life cycle, the most critical factor that influence early startups is money, but due to the particularity of the small- and medium-sized enterprises, it is very difficult for them to obtain loans from the credit market [28]. In this case, as a viable alternative mechanism, the government guiding funds arise. In recent years, venture capital market in China has also been on its stage of prosperity, the emergence of venture investment has opened up a new path of solving the problem of early startup financing. Additionally, the amount of money on venture investment market is limited, which cannot cover all "financing gap" of early startups, so market-oriented venture capital investment cannot completely solve the financing problem of early startup companies. That is to say, startup financing causes the problem of "market failure," and therefore, it is necessary for the government to guide the investment of venture capital and deal with the problem of early startup financing.

We have access to a unique data set containing detailed information about China's new three board companies that have been invested by government guiding funds in the year of 2015-2016, and analyze the influence factors of the timing entering into enterprises of government guiding funds in China. Through the research of this paper, we find the following.

Firstly, government guiding funds entering into the enterprises in developed areas is earlier; on the contrary, the enterprises in the underdeveloped areas obtain the funds later.

Secondly, the innovation ability of the invested enterprises is positively correlated with the investment timing of government guiding funds; that is to say, government guiding funds are more willing to invest in enterprises with low innovation capacity in the initial stage.

Thirdly, the market competitiveness of the invested enterprises is positively related to the opportunity of government guiding funds' entering. Namely, the better the enterprises' market competitiveness is, the later the government guiding funds invest them. 
Last but not least, there is no significant relationship between the share proportion of government guiding funds' investment and the timing of entering into the enterprises.

When we divide the sample data into two groups by the type of industry, we find the following. (1) In subsample of enterprises from the first two industries, the investment timing of government guiding funds has a significantly negative correlation with the innovation ability of the invested enterprises. The coefficient of market competitiveness (POWER) is not significant, and the other variables' significance is the same as that of the full sample. (2) In subsample of enterprises from the tertiary and quaternary industry, the regression results are consistent with the full sample.

\section{Data Availability}

All data used in this study can be obtained from the corresponding author upon request.

\section{Conflicts of Interest}

The authors declare that they have no conflicts of interest.

\section{Acknowledgments}

This work was supported by Beijing Social Science Foundation Project (Project No. 18GLC049), General social science projects of scientific research plan of Beijing $\mathrm{Mu}-$ nicipal Education Commission (Project No. SM201911417006), and the Academic Research Projects of Beijing Union University (Project No. SK20202005; No. XP202011; No. JS10202004).

\section{References}

[1] A. Rahman, "Challenges in privately joint-ventured project: a case study," Journal of Logistics, Informatics and Service Science, vol. 6, no. 2, pp. 90-107, 2019.

[2] W. Ghodbane, "Corporate social responsibility and performance outcomes of high technology firms: impacts on open innovation," Journal of System and Management Sciences, vol. 9, no. 4, pp. 29-38, 2019.

[3] B. Holmstrom and P. Milgrom, "Multitask principal-agent analyses: incentive contracts, asset ownership, and job design," The Journal of Law, Economics, and Organization, vol. 7, pp. 24-52, 1991.

[4] D. Cumming, "Government policy towards entrepreneurial finance: innovation investment funds," Journal of Business Venturing, vol. 22, no. 2, pp. 193-235, 2007.

[5] M. Guerini and A. Quas, "Governmental venture capital in Europe: screening and certification," Journal of Business Venturing, vol. 31, no. 2, pp. 175-195, 2016.

[6] M. Maula, E. Autio, and G. Murray, "Prerequisites for the creation of social capital and subsequent knowledge acquisition in corporate venture capital," Venture Capital, vol. 5, no. 2, pp. 117-134, 2003.

[7] R. Amit, J. Brander, and C. Zott, "Why do venture capital firms exist? theory and Canadian evidence," Journal of Business Venturing, vol. 13, no. 6, pp. 441-466, 1998.
[8] S. Wallsten, The role of government in regional high-tech development: the effects of science parks and public venture capital, 2000.

[9] Y. Pierrakis and G. Saridakis, "Do publicly backed venture capital investments promote innovation? Differences between privately and publicly backed funds in the UK venture capital market," Journal of Business Venturing Insights, vol. 7, pp. 55-64, 2017.

[10] J. Brander, Q. Du, and T. Hellmann, "The effects of government-sponsored venture capital: international evidence," Review of Finance, vol. 19, pp. 1-44, 2015.

[11] A. Croce, L. Grilli, and S. Murtinu, "Venture capital enters academia: an analysis of university-managed funds," The Journal of Technology Transfer, vol. 39, no. 5, pp. 688-715, 2014.

[12] D.-W. Sohn, H. J. Kim, and W. Hur, "Effect of venture capital and government support on the performance of venture firms in Korea," Asian Journal of Technology Innovation, vol. 20, no. 2, pp. 309-322, 2012.

[13] A. Prohorovs and V. Jonina, Whether the Hybrid and Public Venture Capital Funds Are the First Investors of Young Innovative Companies? Social Science Electronic Publishing, Rochester, NY, USA, 2017.

[14] D. Cumming, S. Johan, and J. G. Macintosh, "A drop in an empty pond: Canadian public policy towards venture capital," Economia E Politica Industriale, vol. 44, no. 1, pp. 1-15, 2017.

[15] F. Georgescu, B. Cozmanca, A. M. Cazacu, and A. M. Cojocaru, "Fiscal and income incentives trigger imbalances in a partly functional market economy," Economic Computation and Economic Cybernetics Studies and Research, vol. 54, no. 2, pp. 5-22, 2020.

[16] E. Xing, “An economic model of government's guiding approach in venture capital by the analysis method of microeconomics," Review of Investment Studies, vol. 33, no. 12, pp. 25-42, 2014.

[17] G. P. Shi, X. H. Dang, and J. W. Dong, "Could China's government venture capital guiding funds lead venture capital firms to invest in early-stage enterprises and high- tech enterprises: empirical study with difference-in-differences model," Studies in Science of Science, vol. 34, no. 6, pp. 822832, 2016.

[18] Y. Fang and X. Z. Bao, "Effectiveness of government guiding funds: empirical research based on random effect model," Journal of Technology Economics, vol. 35, no. 2, pp. 58-62, 2016.

[19] Z. H. Li and F. H. Meng, "An analysis on the management mode of government venture capital leading funds," in Proceedings of the International Conference on Management and Service Science, pp. 1-4, IEEE, Wuhan, China, August 2010.

[20] M. L. Yang, W. H. Ding, and L. H. Guo, "The impact of equity participation of GVCGFs on the follow-on fundraising of VCFs," Forecasting, vol. 36, no. 5, pp. 43-48, 2017.

[21] N. Y. Liu and Z. T. Huang, "Research on the development of government venture capital guidance fund," Macroeconomic Management, vol. 32, no. 9, pp. 34-38, 2016.

[22] F. G. Huang, J. Y. Wang, and G. L. Zhu, "The specialization investment of venture capital and the technology innovation of the invested enterprises," Studies in Science of Science, vol. 34, no. 12, pp. 1875-1885, 2016.

[23] M. L. Chen, "Analysis of organization and operation mode of venture capital guiding fund," Review of Investment Studies, vol. 27, no. 9, pp. 49-52, 2010. 
[24] S. Q. Chen, "Logical evolution of government guiding fund," Journal of Central University of Finance \& Economics, vol. 002, pp. 3-13, 2017.

[25] S. U. Xin and Y. Zhou, "New insight into application in mutual funds' performance evaluation on conditional auto regressive expectile models," Chinese Journal of Management Science, vol. 21, no. 6, pp. 22-29, 2013.

[26] D. Xie, Y. Yang, X. Jia et al., "Analysis on path selection to foreign direct investment mode of China's enterprise: based on comprehensive model considering cultural difference, transaction cost and investing motivation," Technology Economics, vol. 35, no. 2, pp. 94-101, 2016.

[27] D. L. Zheng, "Problems and policy suggestions in the process of marketization of government investment funds," Review of Economic Research, vol. 41, pp. 102-105, 2017.

[28] R. Vanaga and B. Sloka, "Financial and capital market commission financing: aspects and challenges," Journal of Logistics, Informatics and Service Science, vol. 7, no. 1, pp. 17-30, 2020. 